\title{
Mechanism of Suppression of Vasopressin during Alpha-Adrenergic Stimulation with Norepinephrine
}

\author{
Tomas Berl, Pravit Cadnapaphornchai, Judith A. Harbottle, and \\ ROBERT W. SchrIER \\ From the Department of Medicine, University of Colorado Medical Center, \\ Denver, Colorado 80220
}

\begin{abstract}
A в S T R A C T Recent studies have demonstrated that the water diuresis associated with intravenous infusion of norepinephrine is mediated primarly by suppression of antidiuretic hormone $(\mathrm{ADH})$ release. To investigate whether the increase in cerebral perfusion pressure with intravenous norepinephrine $(0.5 \mu \mathrm{g} / \mathrm{kg} / \mathrm{min})$ is directly responsible for suppression of $\mathrm{ADH}$ release, the carotid circulation of dogs was pump-perfused bilaterally to selectively increase cerebral perfusion pressure. In six experiments cerebral perfusion pressure was increased from a mean of 125 to $151 \mathrm{~mm} \mathrm{Hg}$ and then returned to $120 \mathrm{~mm} \mathrm{Hg}$. This maneuver was not associated with a reversible increase in renal water excretion. The possibility was also examined that norepinephrine exerts a direct central effect to suppress ADH release. In 12 experiments norepinephrine was infused into the carotid artery in a subpressor dose $(0.12 \mu \mathrm{g} / \mathrm{kg} / \mathrm{min})$ estimated to equal the amount of the catecholamine reaching the cerebral circulation with intravenous norepinephrine. The urinary osmolality (Uosm) was not significantly altered with intracarotid norepinephrine (932 to 959 mosmol $/ \mathrm{kg} \mathrm{H} \mathrm{H}_{2} \mathrm{O}$. The possibility was also examined that changes in autonomic neural tone from arterial baroreceptors is responsible for suppression of $\mathrm{ADH}$ release with intravenous norepinephrine. In sham-operated animals intravenous norepinephrine diminished Uosm from 1,034 to $205 \mathrm{mosmol} / \mathrm{kg} \mathrm{H} \mathrm{H}_{2} \mathrm{O}(P<0.001)$ whereas in animals with denervated arterial baroreceptors intravenous norepinephrine was not associated with a significant alteration in Uosm (1,233 to $1,232 \mathrm{mosmol} / \mathrm{kg})$ $\mathrm{H}_{2} \mathrm{O}$. These different effects on urinary osmolality occurred in the absence of differences in plasma osmolality and volume status. The results therefore indicate that norepinephrine primarily suppresses ADH release by altering autonomic baroreceptor tone rather than by a di-
\end{abstract}

Reccived for publication 9 July 1973 and in revised form 29 August 1973. rect central or pressor effect of the catecholamine. This same mechanism may be the primary pathway for other nonosmotic influences on $\mathrm{ADH}$ release.

\section{INTRODUCTION}

The effect of intravenous norepinephrine to increase renal water excretion has been well documented in both humans (1-3) and animals $(4,5)$. Recent experimental evidence has demonstrated that this effect of norepinephrine is primarily related to its alpha adrenergic-stimulating properties $(4,5)$. Moreover, studies from our laboratory have shown that this effect of norepinephrine on renal water excretion is mediated primarily by suppression of vasopressin release rather than a direct effect on the water permeability of the renal tubular epithelium (6). The mechanism, however, whereby alpha-adrenergic stimulation with norepinephrine may suppress endogenous vasopressin release remains to be elucidated.

The possibility exists that norepinephrine may depress vasopressin release by a direct action on the cells of the hypothalamo-neurohypophysial tract. Alternatively, some consequence of the systemic hemodynamic alterations associated with the intravenous administration of norepinephrine may be involved in the suppression of vasopressin release. Such an effect may primarily involve the increase in systemic arterial pressure which occurs during intravenous norepinephrine. This pressor effect could potentially suppress vasopressin release directly or indirectly by altering afferent baroreceptor neural tone $(7,8)$.

The present investigation was therefore undertaken to examine the mechanism whereby alpha-adrenergic stimulation with intravenous norepinephrine is associated with suppression of vasopressin release independent of changes in plasma osmolality and volume status. The results demonstrate that the intracarotid infusion of subpressor doses of norepinephrine, in an amount compar-

The Journal of Clinical Investigation Volume 53 January 1974-219-227 
able with or greater than that reaching the cerebral circulation during the intravenous infusion of norepinephrine, failed to increase renal water excretion. An increase in cerebral arterial pressure using a pump-perfusion method also failed to alter renal water excretion, even though the rise in cerebral arterial pressure in these experiments was comparable with that observed during the intravenous infusion of norepinephrine. Studies were therefore performed to examine whether an alteration in baroreceptor tone is involved in the effect of intravenous norepinephrine on renal water excretion. These studies demonstrated that alpha-adrenergic stimulation with intravenous norepinephrine was associated with a consistent water diuresis in sham-operated animals but not in animals with denervated arterial baroreceptors. These results therefore indicate that the effect of intravenous norepinephrine on vasopression release is mediated via baroreceptor neural pathways rather than a direct effect of either the catecholamine or arterial pressure on the hypothalamo-neurohypophysial tract.

\section{METHODS}

29 experiments were performed in 19 mongrel dogs of either sex weighing $20-30 \mathrm{~kg}$. In these animals food was withheld $18 \mathrm{~h}$ before study, but water was allowed ad lib. On the day of study the animals were anesthetized with intravenous pentobarbital $(30 \mathrm{mg} / \mathrm{kg})$, intubated, and ventilated with a Harvard respirator (Harvard Apparatus Co., Inc., Millis, Mass.). Light anesthesia was maintained throughout the experiment by the intermittent administration of pentobarbital. All animals received $5 \mathrm{mg}$ of deoxycorticosterone acetate intramuscularly. Polyethylene catheters were placed in both ureters and renal veins through bilateral flank incisions. Denervation of kidneys was performed by stripping and severing the renal nerves and then applying $100 \%$ alcohol to the renal pedicle. In 12 animals an adjustable Blalock clamp was placed around the aorta above the origin of both renal arteries. In all animals catheters were inserted into the aorta via the brachial artery for the continuous measurement of arterial pressure with Statham transducers (Statham Instruments, Inc., Oxnard, Calif.) and a direct writing Gilson recorder (Gilson Medical Electronics, Inc., Middleton, Wis.). In the animals with the Blalock clamp around the aorta, the arterial pressure also was measured in the aorta below the clamp via a catheter inserted in the femoral artery. For the studies in animals with denervated baroreceptors, bilateral cervical vagotomy was performed and the carotid sinus was denervated by stripping and cutting the nerves surrounding the carotid artery at its bifurcation and applying $100 \%$ alcohol to this site. In another group of animals, a sham operation was performed bilaterally in the cervical region with dissection and manipulation of the carotid artery, vagus, and the other surrounding tissues. In the studies in which norepinephrine was infused into the carotid artery, a 23 gauge needle was placed in the left carotid artery and kept patent by a continuous infusion of a $2.5 \%$ solution of glucose and water at $0.5 \mathrm{ml} / \mathrm{min}$. In the carotid artery-perfusion studies a catheter was placed in the abdominal aorta via the femoral artery, passed through a roller pump system and then inserted into the respective carotid artery. With this method, arterial pressure in the carotid arteries was pulsatile and could be altered by adjusting the rate of the perfusion pumps. The carotid sinus baroreceptors were also denervated in these studies so as to prevent reflex baroreceptor-mediated changes in systemic arterial pressure. After completion of surgery, an intravenous infusion of $0.9 \%$ saline $(0.5 \mathrm{ml} / \mathrm{min})$ was begun through a catheter in a foreleg vein which contained sufficient inulin and $p$-aminohippuric acid (PAH) to maintain blood levels of these substances between 15 and 25 and 1 and $3 \mathrm{mg} / 100 \mathrm{ml}$, respectively. A solution of $2.5 \%$ glucose and water was infused into a peripheral vein for $20-30 \mathrm{~min}$ at $20 \mathrm{ml} / \mathrm{min}$ and then maintained at 2-3 $\mathrm{ml}$ above urine flow. After stabilization of urine flow, the experiment was started. Urine was collected at 5- or 10-min intervals throughout the experiment, and arterial and renal venous blood samples were collected at the midpoint of alternate urine collections. The experiments were carried out according to the following protocols.

Bilateral carotid artery perfusion. After adjustment of mean carotid pressure to equal mean systemic pressure, three to five control collections were taken. Carotid arterial pressure was then raised by $20-30 \mathrm{~mm} \mathrm{Hg}$ by adjustment of the pump rates. After a $30 \mathrm{~min}$ equilibration period, three to five experimental urine collections were made. The pressure was then returned to control and after another equilibration period postcontrol collections were made.

Intracarotid administration of norepinephrine. The doses of norepinephrine infused into the carotid artery ranged from 0.10 to $0.13 \mu \mathrm{g} / \mathrm{kg} / \mathrm{min}$. This dose $(20-25 \%$ of the intravenous dose) was chosen to deliver a concentration of the drug to the cerebral circulation which was at least as high as the concentration reaching the head during the studies with intravenous administration of the drug but would not alter systemic hemodynamics. After three to five control periods, norepinephrine was infused into the carotid artery and after an equilibration period of $30 \mathrm{~min}$, three to five experimental urine collections were made. The infusion of norepinephrine was then discontinued and after an equilibration period of $20-30 \mathrm{~min}$, three to five postcontrol urine collections were made.

Intravenous administration of norepinephrine. The same studies were performed in a group of animals with denervated baroreceptors and in a group of sham-operated animals. Except that the drug was infused into the peripheral vein, the experimental protocol was the same as in the studies with intracarotid infusion of norepinephrine.

The analytical procedures used in the present experiments have been referred to elsewhere (9). The following abbreviations will be used: glomerular filtration rate (GFR), renal plasma flow (RPF), renal vascular resistance (RVR), filtration fraction (FF), free-water clearance $\left(\mathrm{C}_{\mathrm{H}_{2} \mathrm{O}}\right)$, and urinary osmolality (Uosm). For statistical analysis, the paired $t$ test was used to evaluate changes in the same animal and the unpaired $t$ test was used to evaluate differences between groups of animals.

\section{RESULTS}

Bilateral carotid artery perfusion studies (Table I, Fig. 1). The purpose of these experiments was to examine whether increases in carotid arterial pressure, such as occur during the intravenous infusion of norepinephrine, are associated with a significant effect on renal water excretion. Results of preliminary investi- 
gations indicated that baroreceptor denervation was necessary to avoid changes in systemic arterial pressure in these studies. As is shown in Table I the bilateral carotid pump-perfusion method was used to increase and decrease carotid arterial pressure by 26 and $31 \mathrm{~mm} \mathrm{Hg}$ respectively as systemic arterial pressure measured in the brachial artery was not significantly altered. The mean values for the six experiments including the effects on renal hemodynamics, electrolyte and water excretion are shown in Table I. The increase in carotid arterial pressure was not associated with either reversible or statistically significant changes in GFR, RPF, or calculated RVR and FF. Urinary sodium and potassium excretion were also not altered by the changes in carotid arterial pressure. Small and progressive decreases in $\mathrm{C}_{\mathrm{H}_{2} \mathrm{O}}$ and Uosm occurred throughout the experiment. The effects on Uosm and $\mathrm{C}_{\mathrm{H}_{2} \mathrm{O}}$ in individual kidneys are plotted in Fig. 1.

Intracarotid norepinephrine studies (Table II). The purpose of these experiments was to investigate whether increased cerebral arterial levels of norepinephrine directly suppress vasopressin release in the absence of alterations in systemic hemodynamics. Norepinephrine was thus infused into the carotid artery in subpressor doses, which were estimated to deliver the same or greater amount of the drug to the cerebral circulation as delivered during previous studies in which intravenous norepinephrine was associated with an increase in renal water excretion (6). In these studies, the systemic arterial pressure was not significantly different before, during, or after the intracarotid infusion of norepinephrine. A reversible increase in arterial hematocrit was, however, observed during the norepinephrine infusion, thus suggesting perhaps some systemic effect of the catecholamine. The mean values for the 12 experiments, including the effects on renal hemodynamics, electrolyte and water excretion are shown in Table II. There was no significant alteration in RPF or calculated RVR and $\mathrm{FF}$ during the infusion of norepinephrine into the carotid artery. A significant increase in GFR did occur during the infusion but this effect was not reversible on cessation of the norepinephrine infusion. The intracarotid infusion of norepinephrine was not associated with significant changes in urinary sodium or potassium excretion. The Uosm and $\mathrm{C}_{\mathrm{H}_{2} \mathrm{O}}$ were also not significantly altered during the intracarotid infusion of the catecholamine.

Intravenous norepinephrine studies in sham-operated and baroreceptor-denervated animals (Tables III and IV, Fig. 2). The purpose of these experiments was to examine the effect of intravenous norepinephrine on renal water excretion in sham-operated animals and animals with cervical denervation of baroreceptors. The results of the effects of intravenous norepinephrine on systemic and renal hemodynamics, electrolyte and water
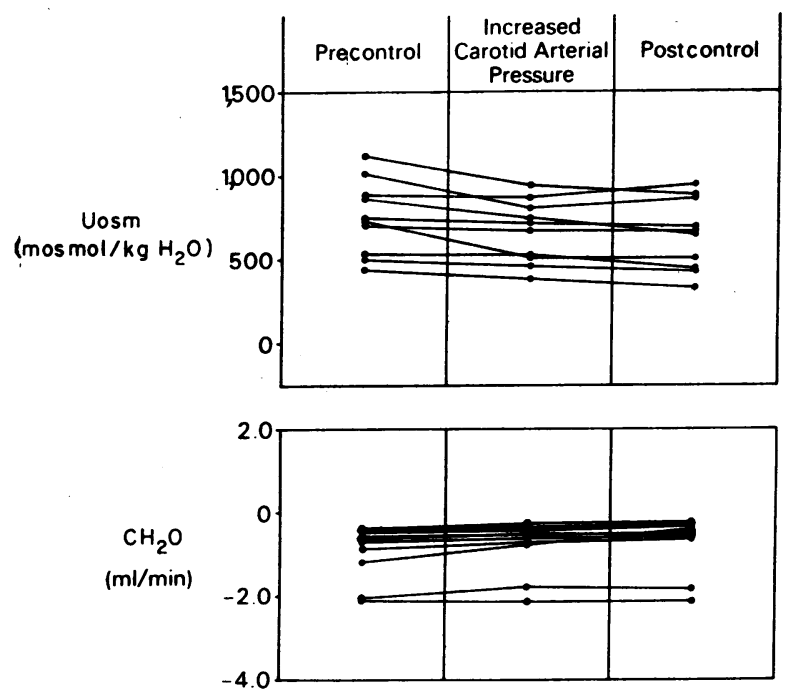

FIGURE 1 Absence of effect of increased carotid arterial pressure on renal water excretion in dogs with denervated baroreceptors. Each point represents the mean value of three to five urine collections for a single kidney. The results of 10 kidneys in 6 animals are shown since 2 kidneys were lost due to surgical mishap while inserting renal venous catheters. The mean level of carotid and systemic arterial pressure for each period is shown in Table I.

excretion in the sham-operated dogs are shown in Table III. These animals responded to norepinephrine infusion in a similar manner as in previous studies in the dog (6). The catecholamine infusion was associated with a marked fall in Uosm from $1,034 \pm 127$ to $205 \pm 25 \mathrm{mosmol} / \mathrm{kg}$ $\mathrm{H}_{2} \mathrm{O}(P<0.001)$ which increased to $771 \pm 62 \mathrm{mosmol} /$ $\mathrm{kg} \mathrm{H}_{2} \mathrm{O}(P<0.001)$ after cessation of the infusion. At the same time $\mathrm{C}_{\mathrm{H}} \mathrm{O}$ increased from $-0.85 \pm 0.11$ to $+0.70 \pm 0.25 \mathrm{ml} / \mathrm{min}$ during the infusion $(P<0.001)$ and decreased to $-0.61 \pm 0.05 \mathrm{ml} / \mathrm{min}$ after the norepinephrine was discontinued $(P<0.001)$. Mean systemic arterial pressure increased $26 \mathrm{~mm} \mathrm{Hg}$ during the intravenous infusion of norepinephrine and decreased $34 \mathrm{~mm}$ $\mathrm{Hg}$ after cessation of the infusion. Renal perfusion pressure was maintained constant throughout these experiments. A small but significant and reversible increase in GFR occurred during the infusion of norepinephrine. $\mathrm{RPF}$ decreased during the norepinephrine infusion thus an increase in FF occurred. In spite of the increase in GFR a significant decrease in sodium and potassium excretion occurred which returned toward control values after cessation of the infusion. This decrease in electrolyte excretion could be related either to a direct or renal hemodynamic effect of the catecholamine but in either case this change in solute excretion was in the opposite direction to explain the observed water diuresis.

The effects of intravenous norepinephrine on systemic and renal hemodynamics, electrolyte and water excretion 
TABLE I

The Effects of Increased Carotid Arterial Pressure on Systemic

\begin{tabular}{|c|c|c|c|c|c|c|c|c|c|}
\hline & \multicolumn{3}{|c|}{ Systemic arterial pressure } & \multicolumn{3}{|c|}{ Carotid arterial pressure } & \multicolumn{3}{|c|}{ GFR } \\
\hline & $\begin{array}{c}\text { Pre- } \\
\text { control }\end{array}$ & $\begin{array}{c}\text { Increased } \\
\text { CAP }\end{array}$ & $\begin{array}{c}\text { Post- } \\
\text { controlf }\end{array}$ & $\begin{array}{l}\text { Pre- } \\
\text { control }\end{array}$ & $\begin{array}{c}\text { Increased } \\
\text { CAP }\end{array}$ & $\begin{array}{l}\text { Post- } \\
\text { control }\end{array}$ & $\begin{array}{c}\text { Pre- } \\
\text { control }\end{array}$ & $\begin{array}{c}\text { Increased } \\
\text { CAP }\end{array}$ & $\begin{array}{l}\text { Post- } \\
\text { control }\end{array}$ \\
\hline & \multicolumn{3}{|c|}{$m m \mathrm{Hg}$} & \multicolumn{3}{|c|}{$m m \mathrm{Hg}$} & \multicolumn{3}{|c|}{$m l / m i n$} \\
\hline $\begin{array}{l}\text { Mean } \\
\pm \mathrm{SE}\end{array}$ & $\begin{array}{r}124 \\
\pm 11\end{array}$ & $\begin{array}{r}129 \\
\pm 12\end{array}$ & $\begin{array}{r}133 \\
\pm 11\end{array}$ & $\begin{array}{l}125 \\
\pm 6\end{array}$ & $\begin{array}{c}151 \\
\pm 6\end{array}$ & $\begin{array}{l}120 \\
\pm 6\end{array}$ & $\begin{array}{r}41.2 \\
\pm 6.2\end{array}$ & $\begin{array}{r}41.2 \\
\pm 6.3\end{array}$ & $\begin{array}{r}41.0 \\
\pm 6.6\end{array}$ \\
\hline$P$ value & \multicolumn{2}{|c|}{ NS\& } & & \multicolumn{2}{|c|}{$<0.001$} & $<0.001$ & & \multicolumn{2}{|c|}{ NS } \\
\hline
\end{tabular}

* The results are the mean values from six experiments; the values for renal hemodynamics and electrolyte and water excretion are expressed per kidney.

$\ddagger$ Precontrol, increased CAP, postcontrol values represent periods before, during, ${ }^{*}$ and after increased carotid arterial pressure (CAP), respectively.

$\&$ NS $=$ not significant $(P$ value $>0.05)$

in dogs with denervated baroreceptors are shown in Table IV. In contrast to the results in the sham-operated animals the intravenous infusion of norepinephrine was not associated with significant alterations in Uosm or $\mathrm{C}_{\mathrm{H}_{2} \mathrm{O}}$ in the animals with denervated baroreceptors (Fig. 2). Uosm was $1,233 \pm 111 \mathrm{mosmol} / \mathrm{kg} \mathrm{H} \mathrm{H}_{2} \mathrm{O}$ before, $1,232 \pm 110 \mathrm{mosmol} / \mathrm{kg} \mathrm{H}_{2} \mathrm{O}$ during, and $1,275 \pm 87$ mosmol/ $\mathrm{kg} \mathrm{H}_{2} \mathrm{O}$ after the norepinephrine infusion respectively. At the same time $\mathrm{C}_{\mathrm{H}_{2} \mathrm{O}}$ decreased significantly from $-0.705 \pm 0.06$ to $-0.533 \pm 0.04 \mathrm{ml} / \mathrm{min}$ $(P<0.001)$ but remained unchanged at $-0.530 \pm 0.04$ after cessation of the infusion. The mean systemic arterial pressure increased $33 \mathrm{~mm} \mathrm{Hg}$ during the intravenous infusion of norepinephrine and then decreased $44 \mathrm{~mm} \mathrm{Hg}$ after cessation of the infusion. As in the sham-operated animals renal perfusion pressure was maintained constant throughout the experiment by adjustment of the suprarenal aortic clamp. GFR and RVR remained unchanged; however, as in the shamoperated animals, FF increased with the norepinephrine infusion and returned to control values after cessation of the infusion. There were no significant changes in sodium or potassium excretion associated with the norepinephrine infusion. The mean systemic arterial pressures in the sham-operated and baroreceptor-denervated animals were also not significantly different. The different effect of intravenous norepinephrine on Uosm and $\mathrm{C}_{\mathrm{H}_{2} \mathrm{O}}$ in the sham-operated and baroreceptor-denervated animals also appeared to be independent of differences in volume status or plasma osmolalities. Hematocrit values were used as a reasonable index of volume status in the two groups of dogs. In the sham-operated animals the mean hematocrits were 45,50 , and $45 \%$ before, during, and after the norepinephrine infusion, respectively, whereas in the baroreceptor-denervated animals the mean hematocrits during the same periods were 45,52 , and $48 \%$. Although norepinephrine significantly increased hematocrit in both groups, none of the values were significantly different between the groups. Significant differences in plasma osmolality also did not account for the different effects of norepinephrine on water excretion. In the sham-operated animals the mean plasma osmolalities were 281,281 , and $278 \mathrm{mosmol} / \mathrm{kg}$ $\mathrm{H}_{2} \mathrm{O}$ before, during, and after the norepinephrine infusion. The water diuresis that occurred during the norepinephrine infusion in these sham animals was thus not related to a decrease in plasma osmolality. Similarly, any potential diuretic effect during the intravenous infusion of norepinephrine in the baroreceptor-denervated animals was not obscured by an increase in plasma

TABLE II The Effects of Intracarotid Infusion of Norepinephrine on Systemic

\begin{tabular}{|c|c|c|c|c|c|c|c|c|c|}
\hline & \multicolumn{3}{|c|}{ Systemic arterial pressure } & \multicolumn{3}{|c|}{ GFR } & \multicolumn{3}{|c|}{ RPF } \\
\hline & $\begin{array}{c}\text { Pre- } \\
\text { control }\end{array}$ & Norepi & $\begin{array}{c}\text { Post- } \\
\text { control* }\end{array}$ & $\begin{array}{l}\text { Pre- } \\
\text { control }\end{array}$ & Norepi & $\begin{array}{l}\text { Post- } \\
\text { control }\end{array}$ & $\begin{array}{c}\text { Pre- } \\
\text { control }\end{array}$ & Norepi & $\begin{array}{l}\text { Post- } \\
\text { control }\end{array}$ \\
\hline & \multicolumn{3}{|c|}{$m m \mathrm{Hg}$} & \multicolumn{3}{|c|}{$\mathrm{ml} / \mathrm{min}$} & \multicolumn{3}{|c|}{$m l / \min$} \\
\hline $\begin{array}{l}\text { Mean } \\
\pm \mathrm{SE}\end{array}$ & $\begin{array}{l}119 \\
\pm 5\end{array}$ & $\begin{array}{r}119 \\
\pm 3\end{array}$ & $\begin{array}{l}117 \\
\pm 4\end{array}$ & $\begin{array}{r}59.5 \\
\pm 2.8\end{array}$ & $\begin{array}{r}64.2 \\
\pm 2.7\end{array}$ & $\begin{array}{r}66.9 \\
\pm 2.2\end{array}$ & $\begin{array}{r}201 \\
\pm 20\end{array}$ & $\begin{array}{r}196 \\
\pm 17\end{array}$ & $\begin{array}{r}223 \\
\pm 16\end{array}$ \\
\hline$P$ value & \multicolumn{2}{|c|}{ NS } & & \multicolumn{2}{|c|}{$<0.02$} & & \multicolumn{2}{|c|}{ NS } & \\
\hline
\end{tabular}

* Precontrol, norepi, postcontrol values represent the mean values for six experiments before, during, and after norepinephrine infusion respectively. The values for renal hemodynamics, electrolyte and water excretion are expressed per kidney. 
and Renal Hemodynamics, Electrolyte and Water Excretion*

\begin{tabular}{|c|c|c|c|c|c|c|c|c|c|c|c|}
\hline \multicolumn{3}{|c|}{$\mathbf{R P F}$} & \multicolumn{3}{|c|}{ Urinary sodium excretion } & \multicolumn{3}{|c|}{$\mathrm{C}_{\mathrm{H}_{2} \mathrm{O}}$} & \multicolumn{3}{|c|}{$\mathrm{U}_{\mathrm{omm}}$} \\
\hline $\begin{array}{c}\text { Pre- } \\
\text { control }\end{array}$ & $\begin{array}{l}\text { Increased } \\
\text { CAP }\end{array}$ & $\begin{array}{l}\text { Post- } \\
\text { control }\end{array}$ & $\begin{array}{c}\text { Pre- } \\
\text { control }\end{array}$ & $\begin{array}{l}\text { Increased } \\
\text { CAP }\end{array}$ & $\begin{array}{l}\text { Post- } \\
\text { control }\end{array}$ & $\begin{array}{c}\text { Pre- } \\
\text { control }\end{array}$ & $\begin{array}{l}\text { Increased } \\
\text { CAP }\end{array}$ & $\begin{array}{l}\text { Post- } \\
\text { control }\end{array}$ & $\begin{array}{c}\text { Pre- } \\
\text { control }\end{array}$ & $\begin{array}{c}\text { Increased } \\
\text { CAP }\end{array}$ & $\begin{array}{l}\text { Post- } \\
\text { control }\end{array}$ \\
\hline \multicolumn{3}{|c|}{$m l / m i n$} & \multicolumn{3}{|c|}{$\mu e q / \min$} & \multicolumn{3}{|c|}{$m l / \min$} & \multicolumn{3}{|c|}{ mosmol/ $/ \mathrm{kg} \mathrm{H}_{2} \mathrm{O}$} \\
\hline 142 & 139 & 134 & 27 & 22 & 20 & -0.95 & -0.80 & -0.76 & 766 & 664 & 650 \\
\hline \multirow{2}{*}{ \pm 19} & \pm 17 & \pm 20 & \pm 10 & \pm 9 & \pm 8 & \pm 0.20 & \pm 0.19 & \pm 0.20 & \pm 74 & \pm 60 & \pm 66 \\
\hline & $\mathbf{S}$ & IS & \multicolumn{2}{|c|}{ NS } & is & \multicolumn{2}{|c|}{$<0.05<<$} & .05 & \multicolumn{2}{|c|}{$<0.05$} & 4s \\
\hline
\end{tabular}

osmolality during the infusion. The plasma osmolalities in this latter group of animals were 277, 272, and 268 mosmol $/ \mathrm{kg} \mathrm{H}_{2} \mathrm{O}$ before, during, and after the norepinephrine infusion.

\section{DISCUSSION}

There is considerable evidence that catecholamines exert an important influence on renal water excretion. The intravenous infusion of norepinephrine has been known for several years to be associated with a water diuresis in both man (1-3) and animals (4-6) and the results of recent experiments indicate that this diuretic effect is due to the alpha-adrenergic stimulating properties of norepinephrine $(4,5)$. Although norepinephrine has been shown to interfere with the in vitro effect of vasopressin on water movement (10), the primary in vivo effect of intravenous norepinephrine appears to be mediated by suppression of endogenous vasopressin (6). This conclusion is derived from recent findings in the dog which demonstrated that intravenous norepinephrine increases renal water excretion in intact dogs but not in acutely hypothesectomized dogs receiving an exogenous infusion of vasopressin (6). Moreover, the direct infusion of norepinephrine into the renal artery of animals, in a dose comparable with that reaching the kidney dur- ing the intravenous studies, does not increase renal water excretion (6).

The purpose of the present investigation was to further investigate the mechanism whereby norepinephrine increases renal water excretion and specifically to attempt to delineate the pathway whereby alpha-adrenergic stimulation with norepinephrine suppresses endogenous vasopressin release. An increase in systemic arterial pressure, such as occurs during the intravenous infusion of norepinephrine, could alter renal water excretion by increasing renal arterial pressure, GFR, or solute excretion rate. Previous experiments in similarly prepared animals, however, have demonstrated that the increase in renal water excretion during intravenous norepinephrine can be disassociated from alterations in these parameters (6). The results of these previous experiments, however, do not exclude the possibility that the increase in systemic arterial pressure at some extrarenal site might be important in the effect of intravenous norepinephrine on renal water excretion. In an effort to investigate whether an increase in cerebral arterial pressure might directly suppress vasopressin release, a pump-perfusion method was used to increase the pressure in both carotid arteries by a magnitude similar to that observed in the studies in which intravenous norepinephrine was administered to

and Renal Hemodynamics, Electrolyte and Water Excretion

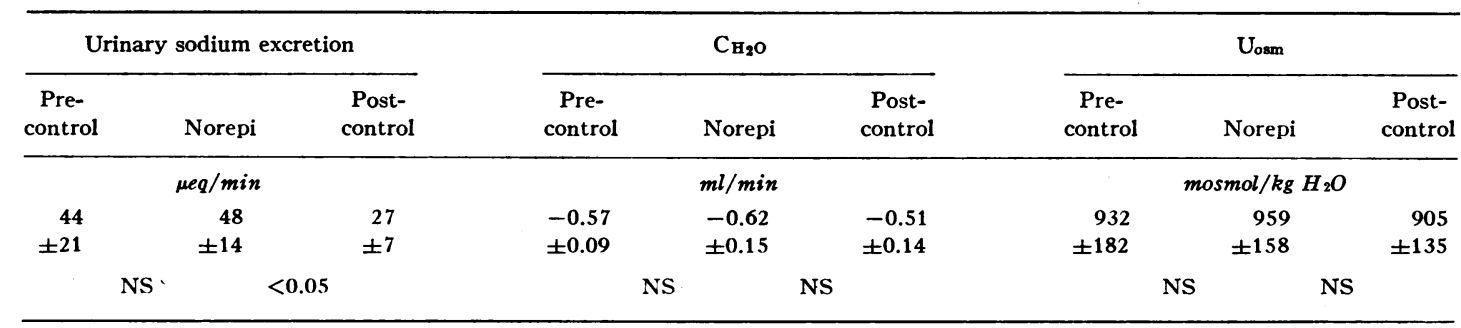


TABLE III

The Effects of Intravenous Norepinephrine on Systemic and Renal Hemodynamics,

\begin{tabular}{|c|c|c|c|c|c|c|c|c|c|}
\hline & \multicolumn{3}{|c|}{ Systemic arterial presssure } & \multicolumn{3}{|c|}{ Renal perfusion pressure } & \multicolumn{3}{|c|}{ GFR } \\
\hline & $\begin{array}{c}\text { Pre- } \\
\text { control }\end{array}$ & Norepi & $\begin{array}{c}\text { Post- } \\
\text { control* }\end{array}$ & $\begin{array}{l}\text { Pre- } \\
\text { control }\end{array}$ & Norepi & $\begin{array}{l}\text { Post- } \\
\text { control }\end{array}$ & $\begin{array}{l}\text { Pre- } \\
\text { control }\end{array}$ & Norepi & $\begin{array}{l}\text { Post- } \\
\text { contro }\end{array}$ \\
\hline & \multicolumn{3}{|c|}{$m m \mathrm{Hg}$} & \multicolumn{3}{|c|}{$m m \mathrm{Hg}$} & \multicolumn{3}{|c|}{$\mathrm{ml} / \mathrm{min}$} \\
\hline $\begin{array}{l}\text { Mean } \\
\pm \mathrm{SE}\end{array}$ & $\begin{array}{l}139 \\
\pm 7\end{array}$ & $\begin{array}{r}165 \\
\pm 12\end{array}$ & $\begin{array}{l}131 \\
\pm 8\end{array}$ & $\begin{array}{l}120 \\
\pm 3\end{array}$ & $\begin{array}{l}120 \\
\pm 3\end{array}$ & $\begin{array}{l}118 \\
\pm 4\end{array}$ & $\begin{array}{r}62.4 \\
\pm 3.6\end{array}$ & $\begin{array}{r}68.0 \\
\pm 3.7\end{array}$ & $\begin{array}{r}63.4 \\
\pm 3.6\end{array}$ \\
\hline$P$ value & \multicolumn{2}{|c|}{$<0.005$} & & \multicolumn{2}{|c|}{ NS } & & \multicolumn{2}{|c|}{$<0.005$} & \\
\hline
\end{tabular}

* Precontrol, norepi, postcontrol values represent the mean values for seven experiments before, during, and after norepinephrine infusion respectively. The values for renal hemodynamics and sodium excretion are expressed per kidney.

the animals. These studies were performed in animals with denervated baroreceptors so that the reflex hypotensive effect of elevating arterial pressure below the level of the aortic and carotid baroreceptors would not occur and thus not complicate the interpretation of any effects on renal water excretion. This experimental design thus allowed for the elevation of cerebral arterial pressure as systemic and renal hemodynamics remained unchanged. The results of these experiments failed to demonstrate an effect of increasing carotid arterial pressure on renal water excretion thus suggesting that cerebral arterial pressure per se is not a direct determinant of vasopressin release. These results, however, did not exclude the possibility that some other cerebral hemodynamic consequence of the norepinephrine infusion might alter vasopressin release or alternatively that the increase in systemic arterial pressure might alter arterial baroreceptor tone in such a manner as to affect vasopressin release. Still another possible mechanism for the effect of intravenous norepinephrine on vasopressin release was that increased cerebral arterial concentrations of norepinephrine might directly suppress vasopressin release.

Some experimental evidence is available suggesting that an increase in norepinephrine concentration in the area of the hypothalamus might alter vasopressin release (11). In this previous study, norepinephrine was injected using micropipettes into the area of the supraoptic nuclei of the rat hypothalamus and a significant decrease in the neurosecretory activity of the cells of these nuclei was observed. Whether this diminution in neurosecretory activity was due to a decrease in vasopressin synthesis, a decrease in vasopressin release or a combination thereof cannot, however, be ascertained. Moreover, it is difficult to compare the norepinephrine concentrations achieved in these microinjection studies with the norepinephrine concentrations reaching the supraoptic nuclei during the intravenous infusion of norepinephrine in the present or previous studies (1-6). If an increase in cerebral arterial concentration of norepinephrine during the intravenous infusion of the catecholamine is primarily responsible for the suppression of vasopressin rather than any systemic hemodynamic consequence of alpha-adrenergic stimulation, then subpressor doses of norepinephrine infused directly into the carotid artery should suppress vasopressin release and produce a water diuresis. In the present studies, if approximately $25 \%$ of cardiac output is distributed to the cerebral circulation, then the dose of norepinephrine infused directly into the carotid arteries should have at least equalled that amount reaching the cerebral circulation during the intravenous norepinephrine studies. This amount of norepinephrine which was infused into the carotid arteries was found to be a subpressor dose of the catecholamine, thus elimi-

TABLE IV

The Effects of Intravenous Norepinephrine on Systemic and Renal Hemodynamics,

\begin{tabular}{|c|c|c|c|c|c|c|c|c|c|}
\hline & \multicolumn{3}{|c|}{ Systemic arterial pressure } & \multicolumn{3}{|c|}{ Renal perfusion pressure } & \multicolumn{3}{|c|}{ GFR } \\
\hline & $\begin{array}{c}\text { Pre- } \\
\text { control }\end{array}$ & Norepi & $\begin{array}{c}\text { Post- } \\
\text { control* }\end{array}$ & $\begin{array}{c}\text { Pre- } \\
\text { control }\end{array}$ & Norepi & $\begin{array}{l}\text { Post- } \\
\text { control }\end{array}$ & $\begin{array}{c}\text { Pre- } \\
\text { control }\end{array}$ & Norepi & $\begin{array}{l}\text { Post- } \\
\text { control }\end{array}$ \\
\hline & \multicolumn{3}{|c|}{$m m \mathrm{Hg}$} & \multicolumn{3}{|c|}{$m m \mathrm{Hg}$} & \multicolumn{3}{|c|}{$m l / m i n$} \\
\hline Mean & 128 & 161 & 117 & 121 & 120 & 114 & 46.7 & 49.7 & 51.5 \\
\hline$\pm \mathrm{SE}$ & \pm 8 & \pm 9 & \pm 8 & \pm 7 & \pm 7 & \pm 7 & \pm 4.1 & \pm 3.4 & \pm 3.6 \\
\hline$P$ value & \multicolumn{2}{|c|}{$<0.001$} & & \multicolumn{2}{|c|}{ NS } & & \multicolumn{2}{|c|}{ NS } & \\
\hline
\end{tabular}

* Precontrol, norepi, postcontrol values represent the mean values for 10 experiments before, during, and after norepinephrine infusion respectively. The values for renal hemodynamics and sodium excretion are expressed per kidney. 
Sodium and Water Excretion in Sham-Operated Dogs

\begin{tabular}{|c|c|c|c|c|c|c|c|c|c|c|c|}
\hline \multicolumn{3}{|c|}{ RPF } & \multicolumn{3}{|c|}{ Urinary sodium excretion } & \multicolumn{3}{|c|}{$\mathrm{C}_{\mathrm{H}_{2} \mathrm{O}}$} & \multicolumn{3}{|c|}{ Uosm } \\
\hline $\begin{array}{c}\text { Pre- } \\
\text { control }\end{array}$ & Norepi & $\begin{array}{l}\text { Post- } \\
\text { control }\end{array}$ & $\begin{array}{c}\text { Pre- } \\
\text { control }\end{array}$ & Norepi & $\begin{array}{l}\text { Post- } \\
\text { control }\end{array}$ & $\begin{array}{c}\text { Pre- } \\
\text { control }\end{array}$ & Norepi & $\begin{array}{c}\text { Post- } \\
\text { control }\end{array}$ & $\begin{array}{c}\text { Pre- } \\
\text { control }\end{array}$ & Norepi & $\begin{array}{l}\text { Post- } \\
\text { control }\end{array}$ \\
\hline \multicolumn{3}{|c|}{$\operatorname{ml} / \min$} & \multicolumn{3}{|c|}{$\mu e q / \min$} & \multicolumn{3}{|c|}{$\operatorname{ml} / \min$} & \multicolumn{3}{|c|}{ mosmol/kg $\mathrm{H}_{2} \mathrm{O}$} \\
\hline 179 & 156 & 169 & 69 & 6 & 17 & -0.85 & +0.70 & -0.61 & 1034 & 205 & 771 \\
\hline \multirow{2}{*}{ \pm 13} & \multirow{2}{*}{$<0.05{ }^{ \pm 15}$} & \pm 14 & \pm 16 & \pm 1 & \pm 4 & \pm 0.11 & \pm 0.25 & \pm 0.05 & \pm 127 & \pm 25 & \pm 62 \\
\hline & & & \multicolumn{2}{|c|}{$<0.025^{ \pm 1}$} & $<0.005^{ \pm 4}$ & \multicolumn{2}{|c|}{$<0.001$} & $<0.001$ & \multicolumn{2}{|c|}{$<0.001<$} & $001^{-1-}$ \\
\hline
\end{tabular}

nating any effects of norepinephrine relating to an increase in systemic arterial pressure. The finding that renal water excretion was unaltered in these intracarotid studies suggested that the effect of intravenous norepinephrine on renal water excretion was not likely to be mediated by any direct or vasoconstrictor effect of increased concentrations of norepinephrine in the cerebral arterial circulation.

The results of the carotid artery perfusion studies and the studies in which norepinephrine was infused into the carotid artery supported the hypothesis that the primary effect of norepinephrine on vasopressin release involved a reflex mechanism initiated by changes in systemic hemodynamics. In this regard, baroreceptor pathways seemed to be the most likely reflex mechanism whereby norepinephrine might alter vasopressin release. Although the results of earlier studies using bioassay techniques to measure vasopressin levels were somewhat conflicting (12-14), more recent investigations indicate that parasympathetic afferent pathways are intimately involved in vasopressin release (8). Experiments were therefore performed in the present investigation to examine whether innervation of aortic and carotid arterial baroreceptors is necessary for the demonstration of the effect of intravenous norepinephrine to increase renal water excretion in animals with an intact hypothalamo-neurohypophysial tract.
The results demonstrated that the effect of intravenous norepinephrine to increase renal water excretion was not demonstrable in animals with denervated baroreceptors. The possibility existed, however, that some nonspecific consequence of the denervation procedure was responsible for the abolishment of the diuretic effect of norepinephrine. A group of sham studies was therefore undertaken in animals in which bilateral cervical operations had been performed. These shamoperated animals demonstrated the same increase in renal water excretion during the intravenous infusion of norepinephrine as previously observed in dogs in which no cervical surgery hàd been performed (6). It is possible that the animals with denervated baroreceptors had endogenous levels of vasopressin which were higher than the sham-operated animals and therefore could not be suppressed by the norepinephrine infusion. However, since both groups of animals received $400-600 \mathrm{ml}$ of fluid before the experiments, and thus did not have maximal urinary osmolalities during the control periods, profound differences in endogenous vasopressin levels should have been associated with substantial differences in urinary osmolalities. The control urinary osmolalities in the sham-operated and baroreceptor-denervated animals were, however, not significantly different. Taken together, the results of the present studies therefore indicate that the effect of

Sodium and Water Excretion in Dogs with Deneriated Baroreceptors

\begin{tabular}{|c|c|c|c|c|c|c|c|c|c|c|c|}
\hline \multicolumn{3}{|c|}{ RPF } & \multicolumn{3}{|c|}{ Urinary sodium excretion } & \multicolumn{3}{|c|}{$\mathrm{C}_{\mathrm{H}_{2} \mathrm{O}}$} & \multicolumn{3}{|c|}{$U_{\text {osm }}$} \\
\hline $\begin{array}{l}\text { Pre- } \\
\text { control }\end{array}$ & Norepi & $\begin{array}{l}\text { Post- } \\
\text { control }\end{array}$ & $\begin{array}{c}\text { Pre- } \\
\text { control }\end{array}$ & Norepi & $\begin{array}{c}\text { Post - } \\
\text { control }\end{array}$ & $\begin{array}{c}\text { Pre- } \\
\text { control }\end{array}$ & Norepi & $\begin{array}{l}\text { Post- } \\
\text { control }\end{array}$ & $\begin{array}{c}\text { Pre- } \\
\text { control }\end{array}$ & Norepi & $\begin{array}{l}\text { Post- } \\
\text { control }\end{array}$ \\
\hline \multicolumn{3}{|c|}{$m l / \min$} & \multicolumn{3}{|c|}{$\mu e q / \min$} & \multicolumn{3}{|c|}{$\mathrm{ml} / \mathrm{min}$} & \multicolumn{3}{|c|}{ mosmol/ $/ \mathrm{kg} \mathrm{H}_{2} \mathrm{O}$} \\
\hline \multirow[t]{2}{*}{ \pm 11} & $\begin{array}{l}109 \\
\pm 8\end{array}$ & $\begin{array}{l}120 \\
\pm 8\end{array}$ & $\begin{array}{r}20 \\
\pm 7\end{array}$ & $\begin{array}{r}4 \\
\pm 1\end{array}$ & $\begin{array}{r}4 \\
\pm 2\end{array}$ & $\begin{array}{l}-0.71 \\
\pm 0.06\end{array}$ & $\begin{array}{l}-0.53 \\
\pm 0.04\end{array}$ & $\begin{array}{l}-0.53 \\
\pm 0.04\end{array}$ & $\begin{array}{c}1233 \\
\pm 111\end{array}$ & $\begin{array}{r}1132 \\
+110\end{array}$ & $\begin{array}{l}1275 \\
\pm 87\end{array}$ \\
\hline & & & \multicolumn{2}{|c|}{$<0.02$} & & & & & & & \\
\hline
\end{tabular}



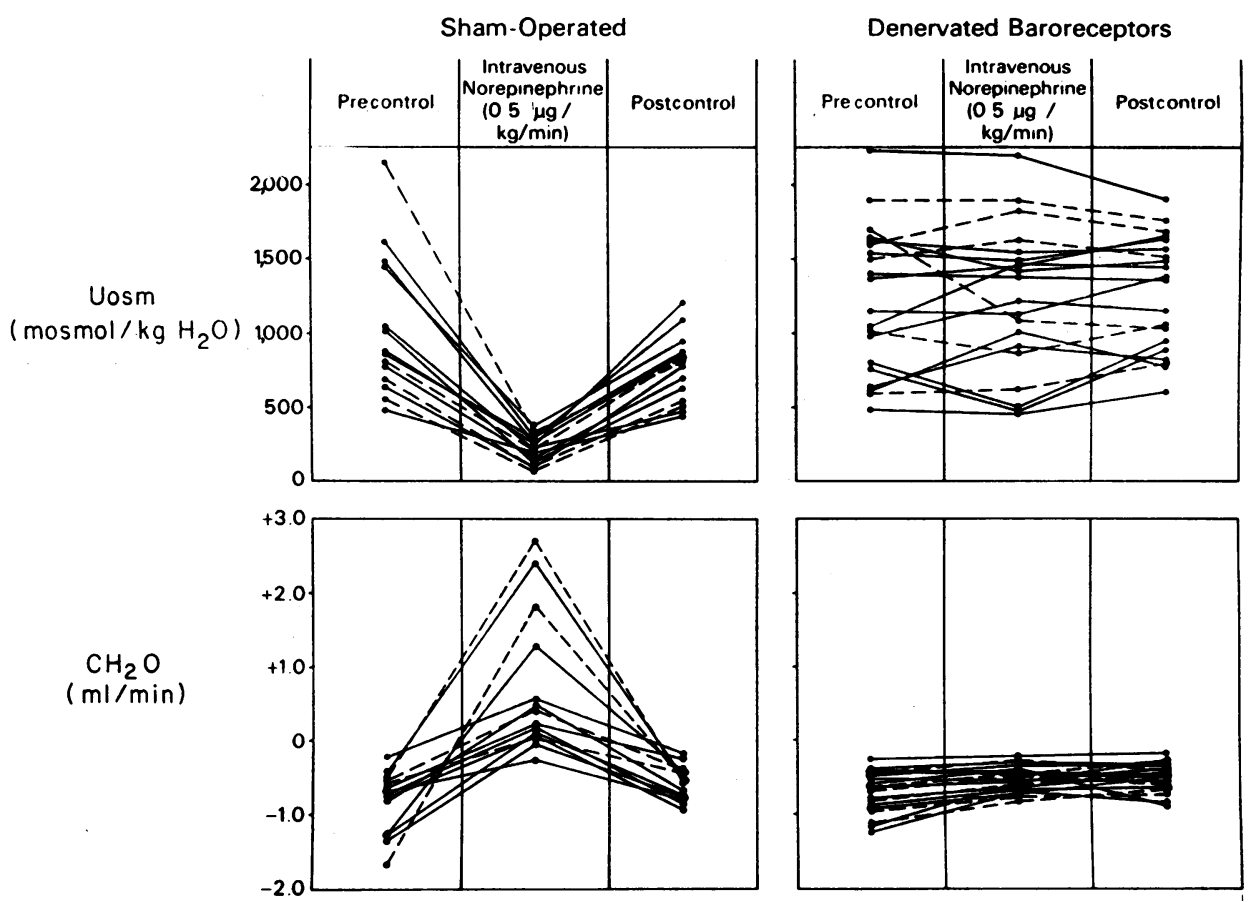

FIGURE 2 Effect of intravenous norepinephrine on $\mathrm{U}_{\mathrm{osm}}$ (above) and $\mathrm{C}_{\mathrm{H}=\mathrm{O}}$ (below) in animals with cervical sham operation (left) and denervation of baroreceptors (right). Denervation of baroreceptors abolished the diuretic effect of intravenous norepinephrine. Each point represents the mean value of three to five urine collections for a single kidney. The broken lines represent results from denervated kidneys and the solid lines represent results from innervated kidneys.

alpha-adrenergic stimulation with intravenous norepinephrine to suppress vasopressin release and increase in renal water excretion (6) is dependent primarily on intact baroreceptor pathways.

It is interesting to note that most circumstances which are associated with an increased release of norepinephrine such as hemorrhage (15) and cardiac failure (16), are most frequently associated with a diminution, rather than an increase, in renal water excretion. Thus, the diuretic effect of intravenous norepinephrine $(1-6)$ has heretofore seemed rather paradoxical. However, since on the basis of the present results the primary effect of norepinephrine on renal water excretion appears to be dependent on a pressormediated alteration in baroreceptor tone, circumstances such as hemorrhage and cardiac failure in which norepinephrine is released as systemic arterial pressure is either constant or diminished would not be expected to increase renal water excretion. In this regard, the antidiuretic effect of beta-adrenergic stimulation with isoproterenol (17) may more closely approximate the situation of impaired water excretion as observed during congestive heart failure and hemorrhage. This effect of beta-adrenergic stimulation with isoproterenol is associated with considerable systemic hemodynamic alterations and is primarily mediated by an increased release of vasopressin (17).

It should also be emphasized that in addition to a role of arterial baroreceptors, an importance of venous stretch receptors may be involved in the diuretic effect of intravenous norepinephrine, since the bilateral cervical vagotomy performed in the present studies interrupted afferent pathways from the left atrium (18). The water diuresis with intravenous norepinephrine (1-6), however, is quantitatively much more pronounced than that observed during the left atrial distention (18-20). Moreover, the water diuresis associated with left atrial distention may not be mediated by suppression of endogenous vasopressin since exogenous infusions of vasopressin have failed to abolish this effect $(19,20)$. Bilateral cervical vagotomy in animals with denervated (21) and innervated hearts (8) have also been shown to similarly diminish renal water excretion, thus suggesting that the important afferent vagal pathways which influence vasopressin release may not involve left atrial stretch receptors.

In summary, the present investigation was designed to examine the mechanism whereby alpha-adrenergic stimulation with intravenous norepinephrine suppresses the endogenous release of vasopressin and thereby 
causes an increase in the renal excretion of solute-free water. No evidence could be obtained that an increased arterial concentration of norepinephrine in the cerebral circulation, either directly or indirectly by a vascular effect, suppresses vasopressin release. Bilateral carotid pump-perfusion studies were also performed to investigate whether an increase in cerebral arterial pressure per se may lead to an increase in renal water excretion and no such diuretic effect was observed. The results of another group of studies, however, did demonstrate that the diuretic effect of intravenous norepinephrine is dependent on intact cervical parasympathetic pathways. These same pathways may be involved in most, if not all, of the nonosmotic influences on vasopressin release.

\section{ACKNOWLEDGMENTS}

We wish to express our gratitude to Mrs. Linda Benson for excellent secretarial assistance and Gary Aisenbrey for excellent technical assistance.

These studies were supported by grants HL 15467-01 and HL 15629-01 from the National Institutes of Health, and a grant from the Hoechst Pharmaceutical Company.

\section{REFERENCES}

1. Smythe, C. McC., J. F. Nickel, and S. E. Bradley. 1952. The effect of epinephrine (USP), 1-epinephrine, and 1-norepinephrine on glomerular filtration rate, renal plasma flow, and the urinary excretion of sodium, potassium, and water in normal man. J. Clin. Invest. $31: 499$.

2. Baldwin, D. S., E. A. Gombos, and H. Chasis. 1963. Changes in sodium and water excretion induced by epinephrine and 1-norepinephrine in normotensive and hypertensive subjects. J. Lab. Clin. Med. 61 : 832.

3. Fisher, D. A. 1968. Norepinephrine inhibition of vasopressin antidiuresis. J. Clin. Invest. 47: 540.

4. Liberman, B., L. A. Klein, and C. R. Kleeman. 1970. Effect of adrenergic blocking agents on the vasopressin inhibiting action of norepinephrine. Proc. Soc. Exp. Biol. Med. 133: 131.

5. Klein, L. A., B. Liberman, M. Laks, and C. R. Kleeman. 1971. Interrelated effects of antidiuretic hormone and adrenergic drugs on water metabolism. Am. J. Physiol. 221 : 1657.

6. Schrier, R. W., and T. Berl. 1973. Mechanism of effect of alpha adrenergic stimulation with norepinephrine on renal water excretion. J. Clin. Invest. 52: 502.

7. Share, L. 1967. Vasopressin, its bioassay and the physiological control of its release. Am. J. Med. 42: 701.

8. Schrier, R. W., and T. Berl. 1972. Mechanism of the antidiuretic effect associated with interruption of parasympathetic pathways. J. Clin. Invest. 51: 2613.

9. Schrier, R. W., and L. E. Earley. 1970. Effects of hematocrit on renal hemodynamics and sodium excretion in hydropenic and volume-expanded dogs. J. Clin. Invest. 49 : 1656.

10. Handler, J. S., R. Bensinger, and J. Orloff. 1968. Effect of adrenergic agents on toad bladder response to $\mathrm{ADH}$, 3',5'-AMP, and theophylline. Am. J. Physiol. 215: 1024.

11. Barker, J. L., J. W. Crayton, and R. A. Nicoll. 1971. Supraoptic neurosecretory cell: adrenergic and cholinergic sensitivity. Science (Wash. D. C.). 171: 208.

12. Perlmutt, J. H. 1964. Effect of vagotomy on renal function during water diuresis. Proc. Soc. Exp. Biol. Med. $116: 270$.

13. Share, L., and M. N. Levy. 1962. Cardiovascular receptors and blood titer of antidiuretic hormone. Am. J. Physiol. 203: 425.

14. Chien, S., B. Peric, and S. Usami. 1962. The reflex nature of release of antidiuretic hormone upon common carotid occlusion in vagotomized dogs. Proc. Soc. Exp. Biol. Med. 111: 193.

15. Dahlstrom, A. B., and B. E. Zetterstrom. 1965. Noradrenaline stores in nerve terminals of spleen: changes during hemorrhagic shock. Science (Wash. D. C.). $147: 1583$.

16. Chidsey, C. A., G. A. Kaiser, E. N. Sonnenblick, J. F. Spann, and E. Braunwald. 1964. Cardiac norepinephrine stores in experimental heart failure in dog. J. Clin. Invest. 43 : 2386.

17. Schrier, R. W., R. Liberman, and R. C. Ufferman. 1972. Mechanism of antidiuretic effect of beta adrenergic stimulation. J. Clin. Invest. 51: 97.

18. Henry, J. P., O. H. Gauer, and J. L. Reeves. 1956. Evidence of the atrial location of receptors influencing urine flow. Circ. Res. 4: 85.

19. Ledsome, J. R., R. J. Linden, and W. J. O'Connor. 1961. Mechanism by which distention of left atrium produces diuresis in anesthetized dogs. J. Physiol. (Lond.). $159: 87$.

20. Lydtin, H., and W. F. Hamilton. 1964. Effect of acute changes in left atrial pressure on urine flow in unanesthetized dogs. Am. J. Physiol. 207: 530.

21. Potkay, S., W. M. Daggett, Jr., and J. H. Gilmore. 1970. Role of the vagus in body water regulation. $\mathrm{Am}$. J. Physiol. 218: 1333. 